\title{
Histological Study on the Effect of Adipose Mesenchymal Stem Cells Derived Microvesicles and the Role of its RNA Content on Original Experimentally-Induced Ulcerative Colitis in Albino Rats
}

\author{
Manal Ali Abdel Mohsen and Marwa Mohamed Sabry
}

Department of Histology, Faculty of Medicine, Cairo University

\begin{abstract}
Background: Ulcerative colitis (UC) is a bowel inflammatory illness, which shows remission and deterioration episodes of abdominal pain and bloody diarrhea. Nowadays, treatment options are not satisfactory other than their various complications. Adipose tissue derived mesenchymal stem cell microvesicles (MSC-MVs) are considered an emerging promising alternative therapeutic agent.

Aim of the work: Evaluation of the therapeutic potential of MSC-MVs on acetic acid (AA) induced UC in addition to the potential role of its RNA content.

Materials and Methods: Forty adult male albino rats were equally divided to 4 groups: group I (control), group II (colitis), group III (MVs treated) and group IV (RNase-MVs treated). Colitis was induced by intracolonic AA enema for groups II, III and IV. On day three after enema a single intravenous injection with either PBS, MSC-MVs or RNase treated MSC-MVs was administered to groups II, III and IV, respectively. Seven days later, colon specimens were harvested and cut equally into two parts. The proximal parts were used for biochemical study to measure myeloperoxidase enzyme (MPO) levels. The distal parts were processed for H\&E, Alcian blue, iNOS and COX-2 immunohistochemistry. Morphometric and statistical analysis were done.

Results: Group III showed improved histological features of UC and marked increase in the mean area percent and optical density of mucin. Also, it showed significant decrease in iNOS and COX-2 immunoreaction and MPO levels.

Conclusion: MSC-MVs administration improved UC features. RNA content of the vesicles proved to have a crucial role in such protective effects. Consequently, MSC-MVs could be a promising tool in UC treatment.
\end{abstract}

Received: 03 February 2019, Accepted: 13 February 2019

Key Words: COX2; iNOS; mesenchymal stem cell microvesicles; rNase; ulcerative colitis.

Corresponding Author: Manal Ali Abdel Mohsen, MD, Department of Histology, Faculty of Medicine, Cairo University, Cairo, Egypt, Tel.: +20 1281726043, E-mail: dr.manal14@hotmail.com

ISSN: 1110-0559, Vol. 42, No. 2

\section{INTRODUCTION}

Inflammatory bowel disease (IBD) is a persistent progressive disabling condition, encompassing both Crohn's disease (CD) and ulcerative colitis (UC). Young persons are the mostly affected, with considerable consequences on social capability and life style ${ }^{[1 \text { and } 2]}$. Currently, the rates of IBD incidence and prevalence are rising by time all over the world, particularly the rate within aged patients ${ }^{[3]}$.

Ulcerative colitis (UC) is a chronic relapsing disease in which gastrointestinal tract inflammation is implicated, affecting mainly colonic mucosa. Increased rate of bloody stools, pain and fever are devastating symptoms of UC. Frequently, symptoms begin at young age and remain all through life. One third of the patients may need surgical removal of the whole colon. Moreover, colorectal carcinoma development risk in UC patients is higher than the healthy population ${ }^{[4,5}$ and 6$]$.
The etiology of UC is still uncertain. Inflammation and immunological dysfunction are implicated in the pathogenesis of UC. Ulcerative colitis has long been a difficult medical problem. Since its discovery and up till now, it is not well solved. Currently, the main stay drugs used in UC management are anti-inflammatory drugs (aminosalicylates and corticosteroids) and immunosuppressant. These therapies help only symptoms of the disease, but long-term relieve of patients cannot be sustained, as they have side effects with prolonged use. Hence, new remedial agents are urgently necessitated to overcome these drawbacks ${ }^{[7}$ and 8$]$.

Mesenchymal stem cells (MSCs) are found within most organs and they possess a multilineage differentiation capability. The MSCs with their regenerative, immunomodulatory and anti-inflammatory properties are capable of repairing UC injured mucosa ${ }^{[9,10}$ and 11]. 
MSCs benefits do not count on their differentiation and capability of injured tissue replacement. Rather than, they are mainly mediated by their paracrine effects, involving discharge of factors such as extracellular vesicles (EVs) which are comprised of microvesicles and exosomes ${ }^{[12]}$.

Mesenchymal stem cells, similar to numerous other kinds of cells, have the ability to discharge extracellular vesicles (EVs) like microvesicles and exosomes to the extracellular enviroment. These vesicles can be uptaken and internalized by recipient cells. A variety of biologically active molecules are enclosed inside EVs including proteins and bioactive lipids. Also, they contain DNA and messenger RNA in addition to noncoding RNA e.g. microRNA and long noncoding RNA (lncRNA). Subsequent delivery of these contents to target cells can mediate functional effects ${ }^{[13}$ and 14] .

This study was planned to detect the possible protective effect of microvesicles (MVs), released by adipose tissue derived mesenchymal stem cells (ADMSCs), on experimental ulcerative colitis. Furthermore, the role of RNA content of MVs in exerting such effect was investigated.

\section{MATERIALS AND METHODS}

\section{Animals and experimental design}

This study included 40 adult male albino rats, 180$200(184 \pm 1.35)$ gm body weight. Animals were housed in hygienic stainless steel cages and kept in clean well ventilated room. They were fed standard chow diet and allowed water ad libitum. All procedures were held in accordance with the guidelines of the Animal Ethical Committee of Kasr Alainy Faculty of Medicine, Cairo University.

\section{Rats were divided into the following four groups}

Group I (control group) ( $\mathrm{n}=10)$ : were subjected to intracolonic $0.9 \%$ saline enema. On day three following enema, they received single intravenous (IV) injection, through caudal vein, of $1 \mathrm{ml}$ PBS.

All rats in groups II, III and IV were subjected to intracolonic acetic acid (AA) enema to induce experimental colitis. On day three following enema, animals in these groups received the following:

Group II (colitis group) $(\mathrm{n}=10)$ : rats received single IV injection, through caudal vein, of $1 \mathrm{ml}$ PBS.

Group III (MVs treated group) $(\mathrm{n}=10)$ : rats received single IV injection, through caudal vein, of $200 \mu \mathrm{g}$ MVs diluted with $1 \mathrm{ml}$ PBS.

Group IV (RNase-MVs treated group) $(n=10)$ : rats received single IV injection, through caudal vein, of $200 \mu \mathrm{g}$ RNase treated MVs diluted with $1 \mathrm{ml}$ PBS.

Animals were sacrificed by cervical dislocation on day seven after caudal vein injections ${ }^{[15]}$.
Laparotomy was done and colons were dissected. Distal $10 \mathrm{~cm}$ segment of colon proximal to the anus were excised. This segment was divided into proximal and distal parts. The proximal part was utilized for biochemical analysis and the distal part was processed for histological examination. This is because histological changes in experimentally induced UC using AA enema, affects mainly the distal part of the colon ${ }^{[16 \text { and } 17]}$.

\section{Induction of experimental colitis}

Each animal received $2 \mathrm{ml}$ of acetic acid (AA) (4\% $\mathrm{v} / \mathrm{v}$ in $0.9 \%$ saline, that was prepared at Biochemistry Department, Kasr Al-Ainy Medical School) through intra colonic enema in order to induce colitis. Rats had free access to water, however $12 \mathrm{hrs}$ of food restriction was followed. They underwent anesthesia with ketamine and xylazine $(5 \mathrm{mg} / \mathrm{kg}$ each, i.p.). Then a soft $6 \mathrm{~F}$ pediatricfeeding catheter was inserted into the anus of each animal and the tip was advanced to $8 \mathrm{~cm}$. This was followed by administration of AA into the catheter. Before pulling out the catheter, $2 \mathrm{ml}$ of air were injected to make AA spread throughout the colon. The catheter was then withdrawn gradually to avoid any trauma. Afterward, animals were upturned by tail for 30 seconds to avoid any escape of the administered $\mathrm{AA}^{[18 \text { and 19]. }}$

Preparation of mesenchymal stem cell derived microvesicles and RNase treated microvesicles

Adipose derived, PKH26 labeled, mesenchymal stem cell microvesicles (MSC-MVs) were purchased from Biochemistry Department, Kasr Al-Ainy Medical School. The protocol used for preparation of MVs was similar to that was previously used ${ }^{[20 \text { and 21] }}$. MVs were treated with RNase, in order to deplete its RNA content, according to a previously used method ${ }^{[22]}$.

\section{Administration of MSC-MVS}

On the third day after enema, group III and group IV received $200 \mu \mathrm{g}$ of labeled MSC-MVs and $200 \mu \mathrm{g}$ of RNase treated labeled MSC-MVs, respectively. MVs were diluted with $1 \mathrm{ml}$ of PBS and injected through caudal vein in each animal. Rats were sacrificed on the seventh day after injection ${ }^{[23]}$.

\section{Biochemical study}

Assessment of myeloperoxidase activity (MPO) was done at the Biochemistry Department, Kasr AlAiny Medical School. Rat myeloperoxidase ELISA kit (MyBioSource Inc., Cat.No: MBS046496) was used to measure MPO levels in colon homogenates in line with the manufacturer's method.

MPO enzyme exists inside neutrophils' granules and its activity level reflects the grade of these cells tissue infiltration. MPO is released from neutrophils during inflammation. This leads to creation of free radicals, that aquire a strong bactericidal effects. However, these free radicals also result in host cells damage ${ }^{[24]}$. 


\section{Histological study}

Colon samples dissected from all rats were subjected to fixation in $10 \%$ buffered formalin solution for $24-48$ hours, dehydration in ascending grades of ethanol and embedding in paraffin. Six $\mu \mathrm{m}$ thickness serial sections were sliced and subjected to the followings:

1. Hematoxylin \& eosin (H\&E) stain to evaluate histological mucosal changes ${ }^{[25]}$.

2. Alcian blue stain to detect mucin secreting cells ${ }^{[26]}$.

3. Immunohistochemical staining using the following primary antibodies: ${ }^{[27]}$

1. Inducible nitric oxide synthase (iNOS): this generates nitric oxide (NO) via catalyzing the transformation of 1-arginine into 1-citrulline. It has an important role in intestinal inflammation pathogenesis. Colonic iNOS expression correlates with the activity of UC disease ${ }^{[28]}$.

2. Cyclooxygenase enzyme-2 (COX-2): which is a proinflammatory mediator and its activity reflects the severity of colonic inflammation ${ }^{[29]}$.

Sections were incubated with either anti iNOS antibody or anti COX-2 antibody. Both of them were a rabbit polyclonal antibody (Lab Vision Corporation Laboratories). The used technique was avidin-biotin peroxidase complex. The detection system histostain SP kit was used (LABSA system, Zymed Laboratories Inc, SF, USA). Counter staining of nuclei was done using Mayer's haematoxylin stain. Positive iNOS immunoreactivity appears as brown cytoplasmic deposits. Positive COX-2 immunoreactivity appears as brown cytoplasmic deposits and sometimes nuclear membrane brown discolouration.

4. Unstained sections were used to detect PKH26 labeled MSC-MVs and RNase treated MSC-MVs using fluorescent microscopy (Olympus BX50F4, No. 7M03285, Tokyo, Japan).

\section{Morphometric analysis}

This was carried out using Leica Qwin 500 LTD image analyzer (Leica, Cambridge, UK). All measurements were taken in five sections from each animal. The mean area percent and optical density of mucin were measured in 10 random non overlapping fields per section using binary mode with $\times 10$ objective lens. The mean area percent of iNOS and COX2 immunoreactivity were measured using $\times 40$ objective lens.

\section{Statistical analysis}

All measurements were demonstrated as mean $\pm \mathrm{SD}$. Calculations were done using SPSS software version 16 (Chicago, USA). Differences between groups were evaluated by Analysis of Variance test (ANOVA) and after that post hoc test. A statistical significance was indicated when $P<0.05^{[30]}$.

\section{RESULTS}

Biochemical results

\section{Myeloperoxidase (MPO) enzyme activity levels}

Measurements of MPO level in colon specimens of both group II and group IV revealed significantly increased values $(p<0.05)$ versus control. A statistically significant decrease $(p<0.05)$ in MPO level activity of group III in comparison with both group II and group IV was detected (Table 1).

\section{Histological results}

\section{Confirmation of homing of MSC-MVs into the colon}

Detection of PKH26 labeled MSC-MVs was done using fluorescent microscopy in unstained colonic sections. Sections in the colon of both groups III and IV showed the prescence of PKH26 labeled MSC-MVs. It was detected within the connective tissue lamina propria and epithelium of the mucosa (Figure 1). MSC-MVs exhibited strong red autofluorescence (red fluorescent dots), confirming that these vesicles migrated to colonic tissues.

\section{Haematoxylin and eosin stained sections}

Colon sections in the control group illustrated normal histological architecture of the mucosa layer demonstrating numerous, regularly arranged, evenly spaced and tightly packed crypts. They occupy the whole thickness of the mucosa resting on the muscularis mucosa. The surface epithelium and crypt lining are formed mainly of simple columnar absorptive cells and goblet cells. The simple columnar absorptive cells become fewer as we go deeper in the crypt, while goblet cells become more numerous. Connective tissue lamina propria houses normally resident immune cells mainly lymphocytes (Figure 2).

Examination of colon sections of group II showed many features of mucosa affection in UC in the form of complete destruction of crypts architecture with the appearance of dilated irregular crypts. Accumulation of inflammatory cells inside crypt was also noted. Loss of surface epithelium was detected. Very few number or complete absence of goblet cells was also seen. The lamina propria was massively infiltrated with inflammatory cells which are mainly lymphocytes. In addition, eosinophil and polymorph nuclear leukocyte was observed (Figure 3).

Sections in the colon of group III showed apparently normal histological architecture. Mucosa exhibited preserved crypts with intact continuous surface epithelium and numerous goblet cells (Figure 4).

On examination of colon mucosal sections of group IV, similar morphological alterations to group II were observed. Moreover, widening of the spaces between crypts indicating crypt loss was observed. Accumulation of inflammatory cells including polymorph nuclear leukocytes inside crypt lumen was noted (Figure 5). 


\section{Alcian blue stained sections}

Examinations of sections of group I showed numerous deeply stained goblet cells in the crypts lining (Figure 6A). Sections in mucosa of group II showed apparently few goblet cells, in addition to reduction in the intensity of alcian blue staining (Figure 6B). Sections in mucosa of group III exhibited marked increase in both goblet cells number and mucin staining intensity in relation to groups II and IV (Figure 6C). Similar findings to group II were detected on examination of sections in the mucosa of group IV (Figure 6D).

\section{Immunohistochemical results}

\section{iNOS immunostained sections}

Sections in the colon of group I showed very scanty brown cytoplasmic positive immunoreactivity in the epithelium and few cells in the connective tissue lamina propria of mucosa (Figure 7A). Examination of sections of group II exhibited marked increase in iNOS positive immunoreactivity in both epithelial and lamina propria cells in relation to control (Figure 7B). Sections in mucosa of group III demonstrated remarkable decrease in positive immunoreactivity compared to both groups II and IV (Figure7C). Sections of group IV exhibited comparable positive immunoreactivity to group II (Figure 7D).

\section{COX-2 immunostained sections}

Examination of sections in the colon of group I showed

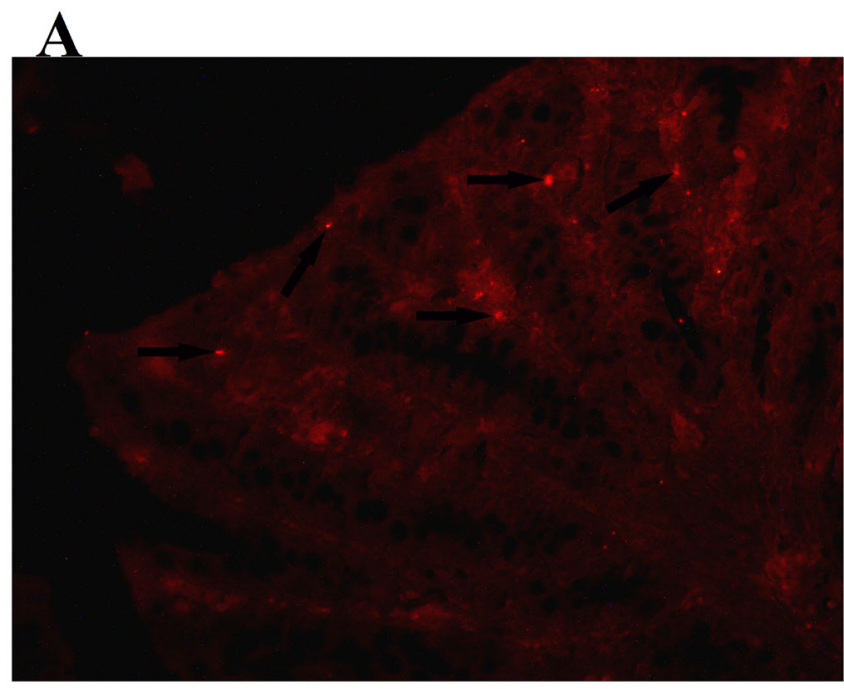

weak brown cytoplasmic positive immunoreaction in the surface epithelium and few connective tissue lamina propria cells (Figure 8A). Sections of group II demonstrated marked increase in COX-2 positive immunoreaction in both epithelial and lamina propria cells in relation to control. COX-2 positive immunoreactivity was up regulated in both the cytoplasm and the nuclear membrane (Figure 8B). Sections in mucosa of group III exhibited marked decline in COX-2 immunopositive cells in comparison to both groups II and IV (Figure 8C). Examination of sections of group IV showed same positive immunoreactivity compared to group II (Figure 8D).

\section{Morphometric results}

Morphometric results of groups II and IV demonstrated significantly decreased values $(p<0.05)$ for the mean area $\%$ and optical density of mucin versus control. Conversely, group III revealed a significant increase in the mean area $\%$ and optical density of mucin in comparison with groups II and IV (Table 2). Regarding mean area $\%$ of iNOS positive immunoreactivity, both groups II and IV exhibited statistically significant increase $(P<0.05)$ when compared with control. Statistically significant decrease $(P<0.05)$ was reported in group III versus groups II and IV (Table 2). Mean area \% of COX-2 immunoreactivity in both group II and group IV illustrared a significant increase $(p<0.05)$ when in comparison with control. Group III revealed statistically significant decrease $(P<0.05)$ in comparison with groups II and IV (Table 2).

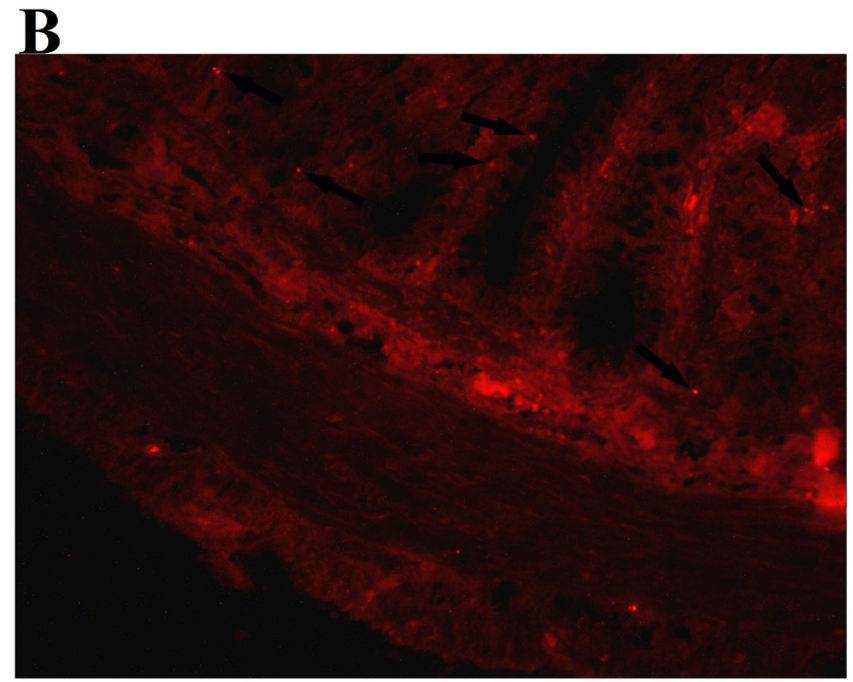

Fig. 1: Photomicrograph of a section in the colon of:

A: MVs treated group illustrating the presence of PKH26 labeled MVs (arrows) in the mucosa. B: RNase-MVs treated group showing the presence of PKH26 labeled MVs (arrows) in the mucosa.

(Fluorescent microscopy image: A and B x200) 


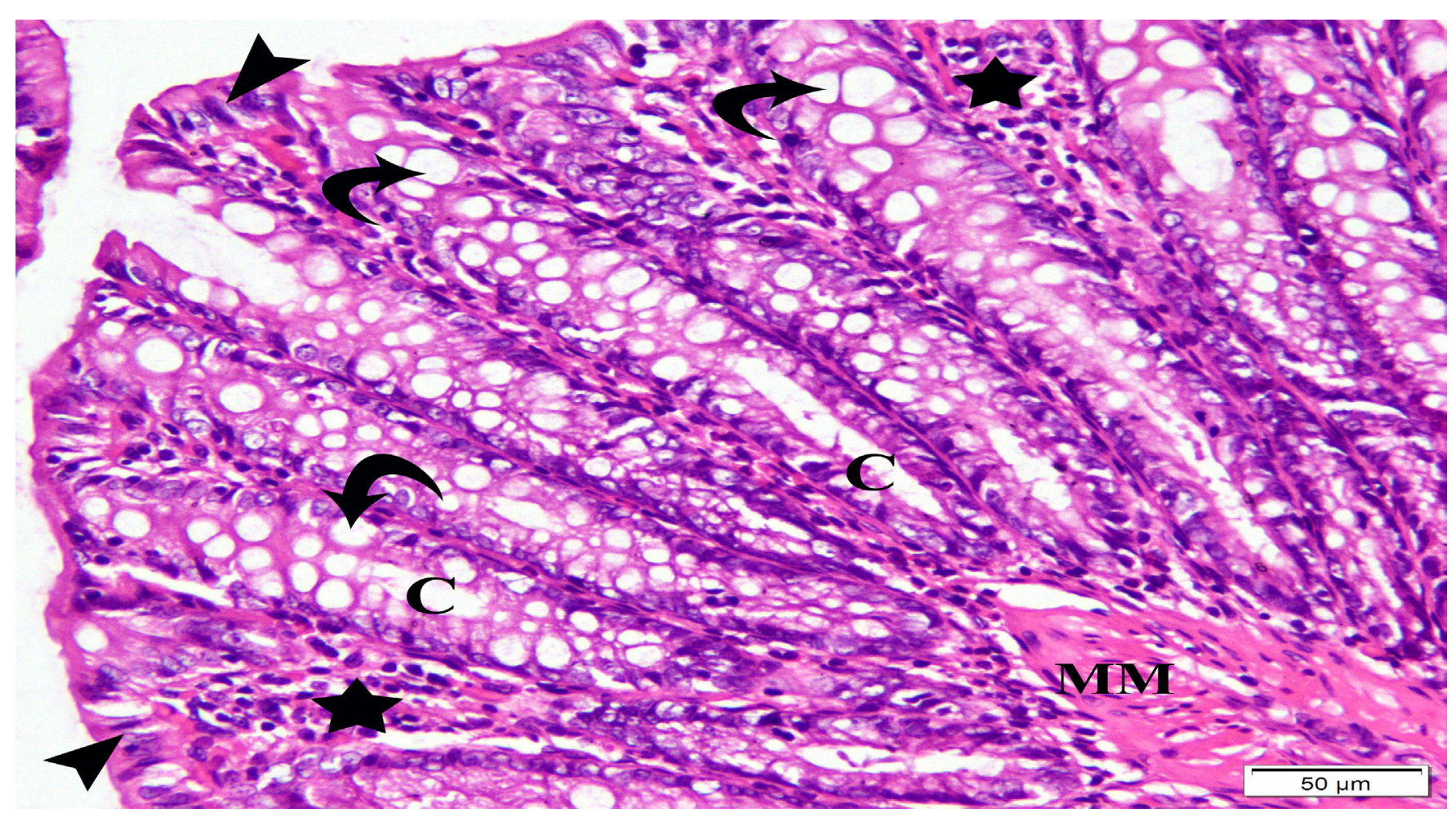

Fig. 2: Photomicrograph of a section in the colon of control group demonstrating normal histological architecture of mucosa of the colon. Mucosa is formed of regularly arranged, evenly spaced and tightly packed crypts (C) occupying the whole thickness of the mucosa resting on the muscularis mucosa (MM). Intact surface epithelium and crypt lining formed mainly of simple columnar absorptive cells (arrowheads) and goblet cells (curved arrows). Numerous immune cells mainly lymphocytes are detected in the lamina propria (star).

$(\mathrm{H} \& \mathrm{E}, \mathrm{x} 200)$
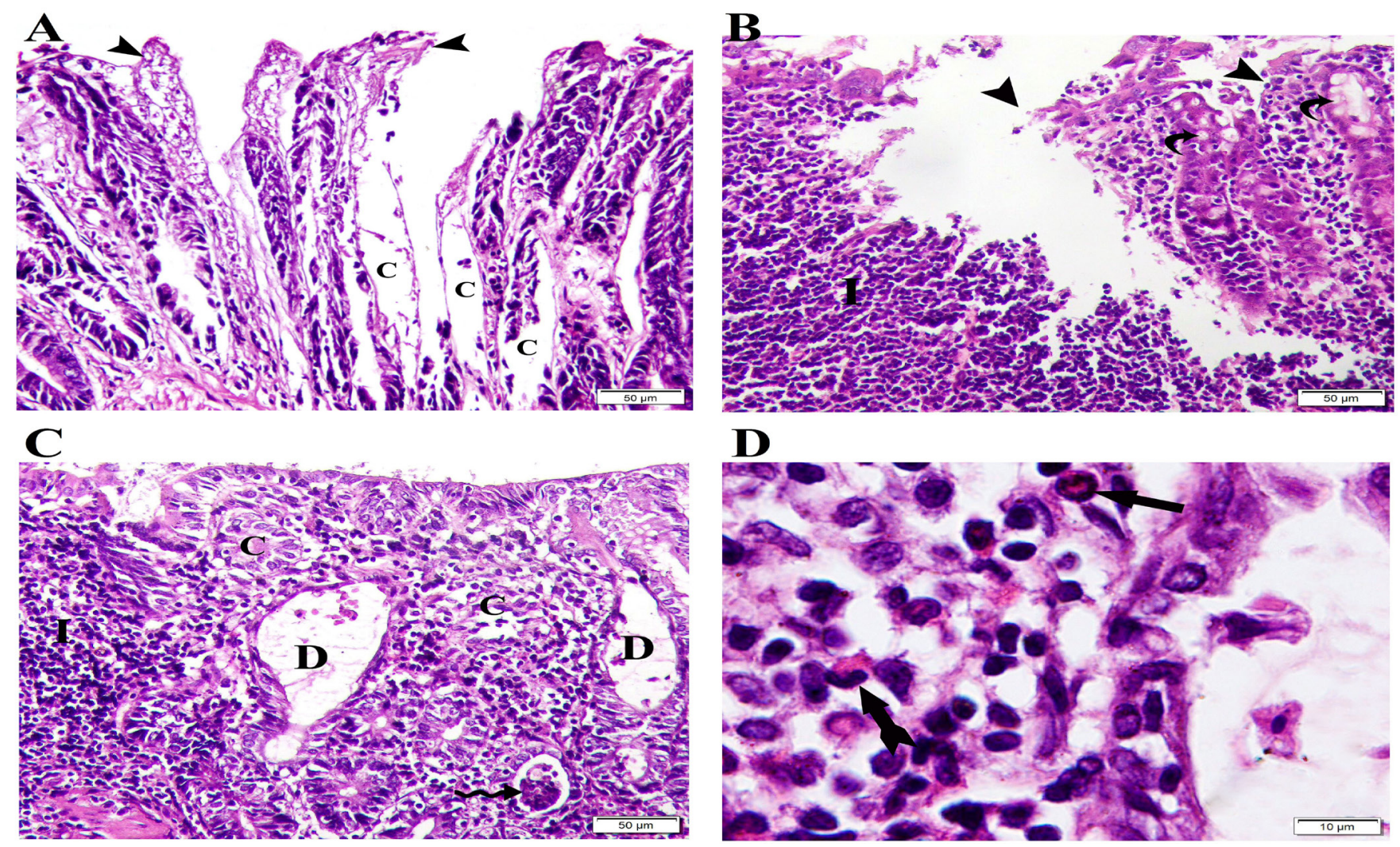

Fig. 3: Photomicrograph of a section in the colon of colitis group expressing; A: Complete destruction (C) of crypts architecture. Loss of surface epithelium is noted (arrowheads). Absence of goblet cells is also seen. B: Massive infiltration with inflammatory cells (I) mainly lymphocytes is clearly noted in the lamina propria. Very few goblet cells can be seen (curved arrows). C: Destruction of crypt architecture (C) is noticed. Heavy infilteration of the lamina propria with inflammatory cells is clearly seen (I). Dilated irregular crypts (D) are also detected. Accumulation of inflammatory cells inside crypt can be noted (wavy arrow). D: Note the presence of polymorph nuclear leukocyte (PMNL) (arrow) and eosinophil (bifid arrow) in the lamina propria. (H\&E: A, B and C x200; Dx1000) 


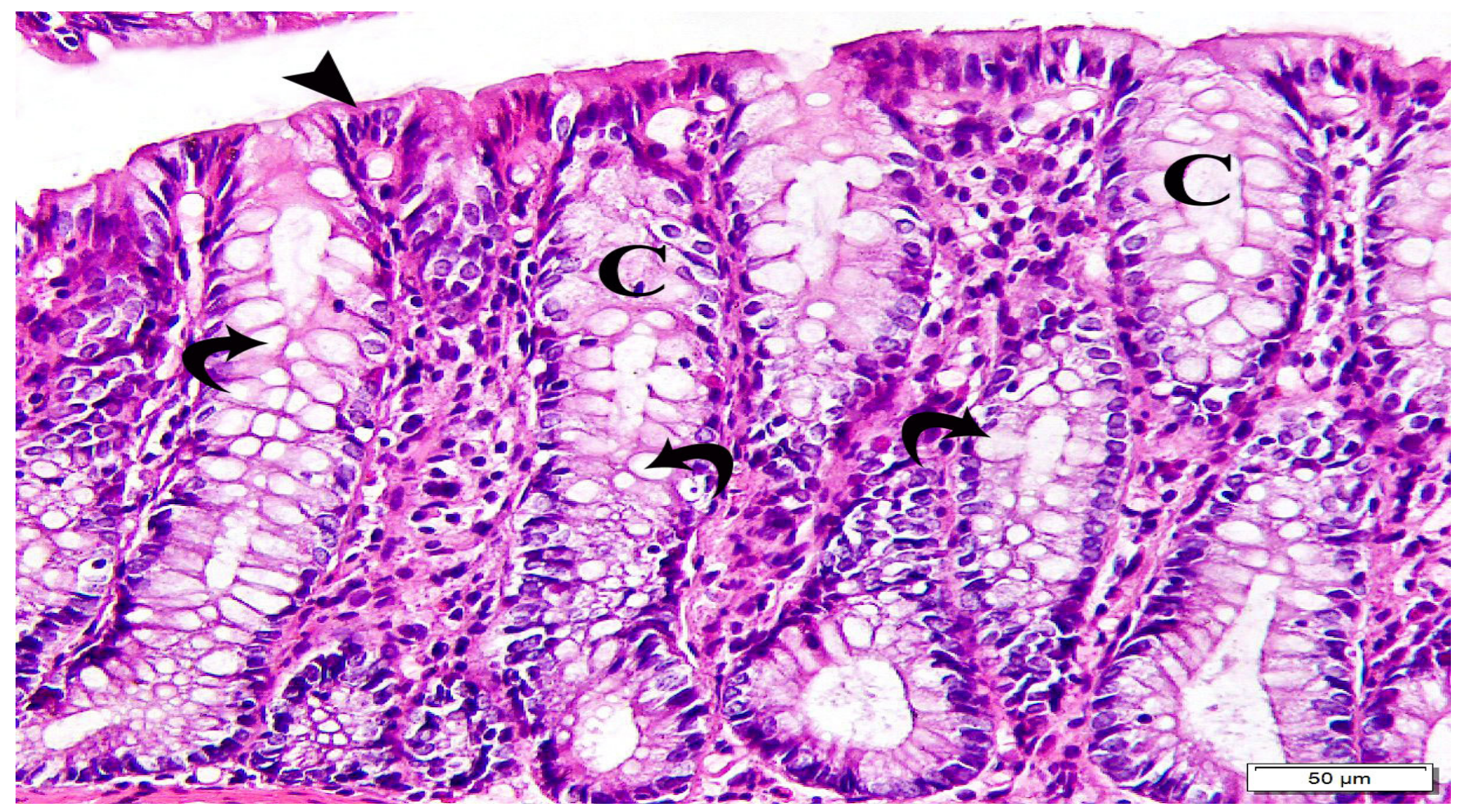

Fig. 4: Photomicrograph of a section in the colon of MVs treated group demonstrating mucosa with preserved crypts architecture (C) and numerous goblet cells (curved arrows). Intact continuous surface epithelium (arrowhead) is also noted.

$(\mathrm{H} \& \mathrm{E}, \mathrm{x} 200)$
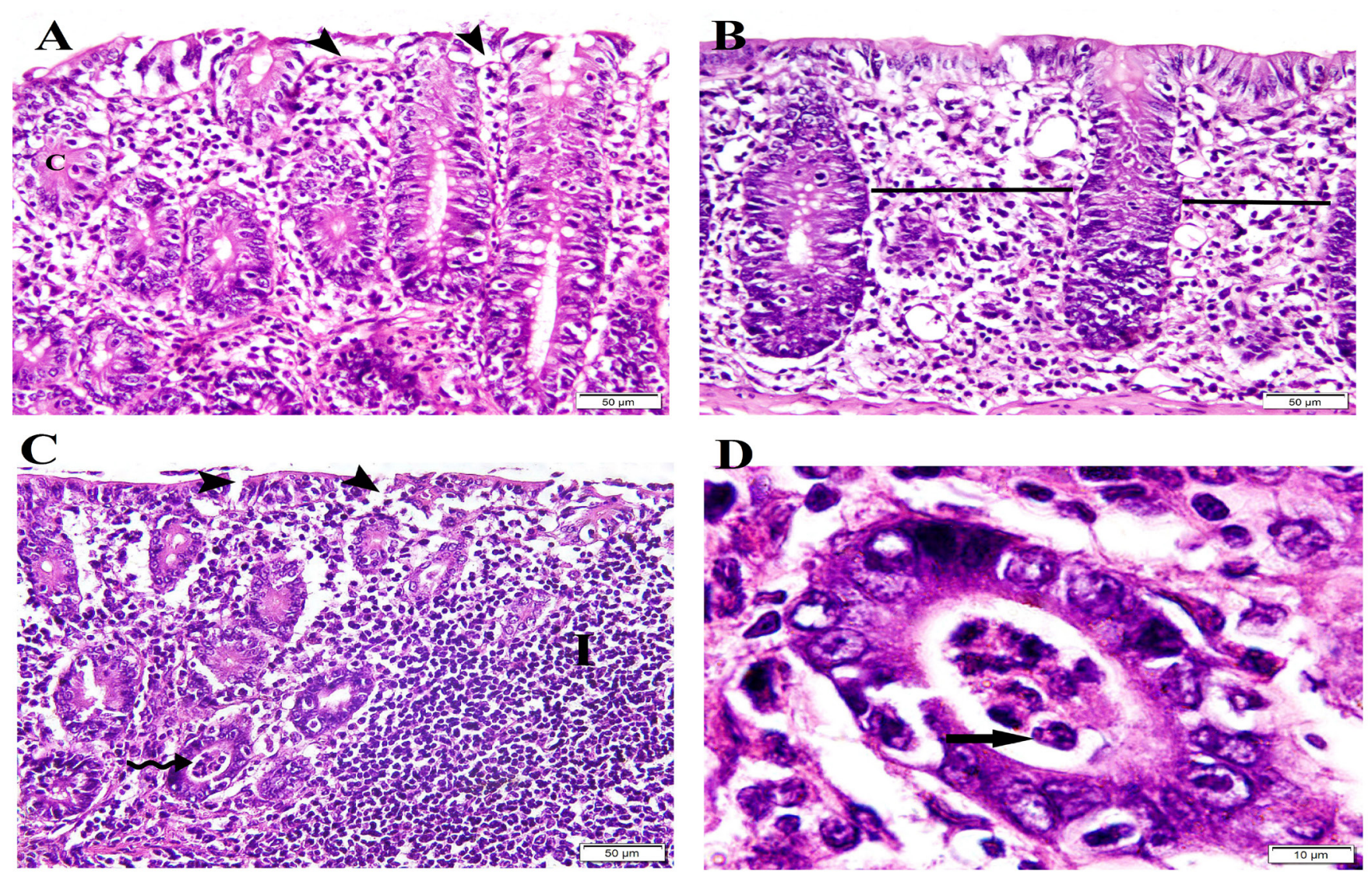

Fig. 5: Photomicrograph of a section in the colon of RNase-MVs treated group revealing; A: loss of surface columnar epithelial lining (arrowheads) in some areas. Disturbed crypts architecture is noted (C). Loss of goblet cells is also observed. B: Widening of the spaces between crypts (lines) can be seen. C: Loss of surface epithelial lining is detected (arrowheads). Heavy inflammatory cells infiltration (I) mainly lymphocytes can be detected in the lamina propria. Accumulation of inflammatory cells inside the crypt can be also seen (wavy arrow). D: Note the appearance of PMNL (arrow) inside lumen of the crypt. 

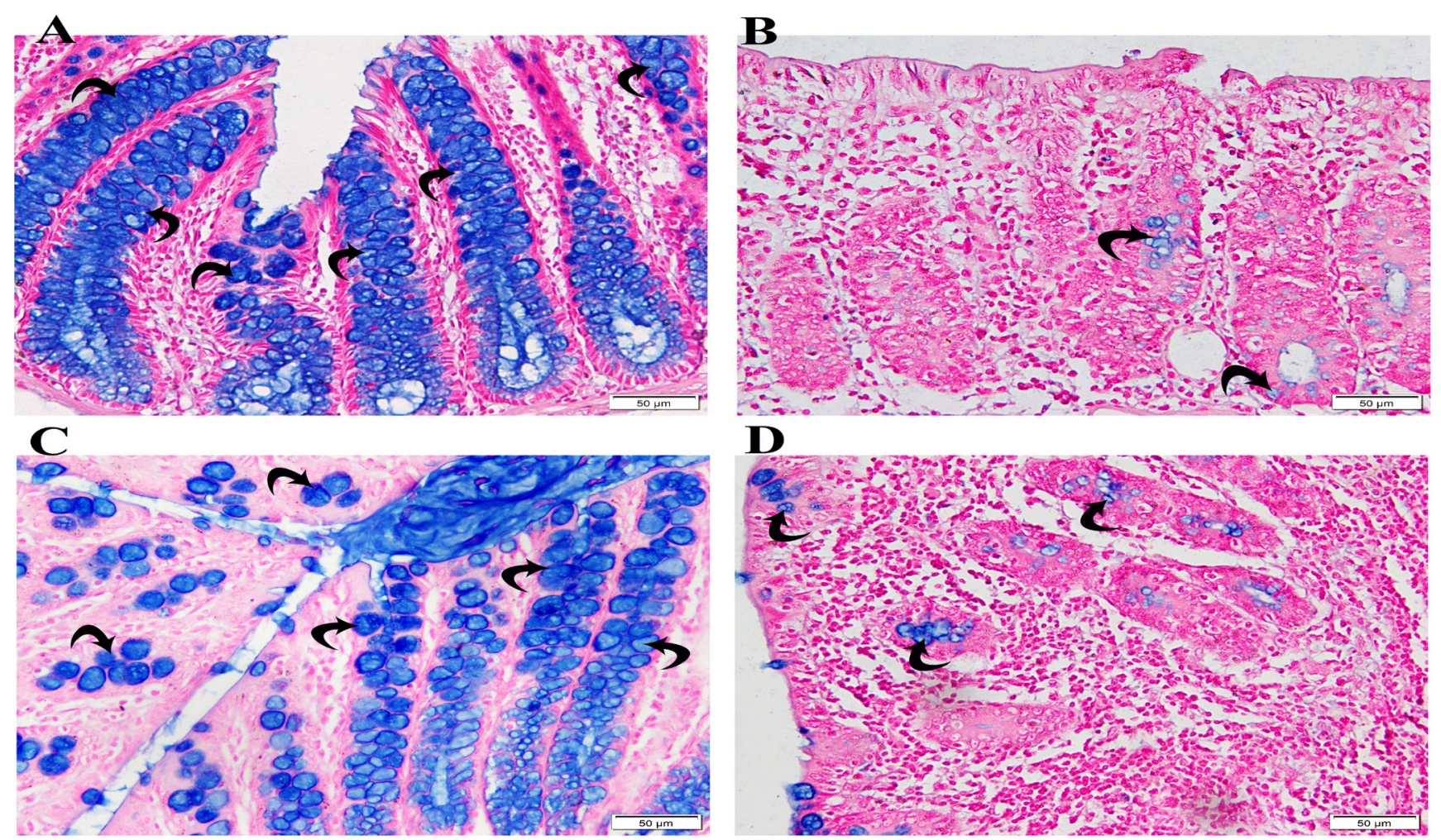

Fig. 6: Photomicrograph of a section in the colon of:

A: Control group illustrating numerous alcian blue stained goblet cells (curved arrows). B: Colitis group demonstrating apparently few goblet cells (curved arrows) with reduction in the intensity of alcian blue staining. C: MVs treated group revealing numerous goblet cells (curved arrows). D: RNase-MVs treated group exhibiting apparently few goblet cells (curved arrows) with decline in the intensity of alcian blue +ve mucin staining. （Alcian blue: A,B,C \& D x200)

A
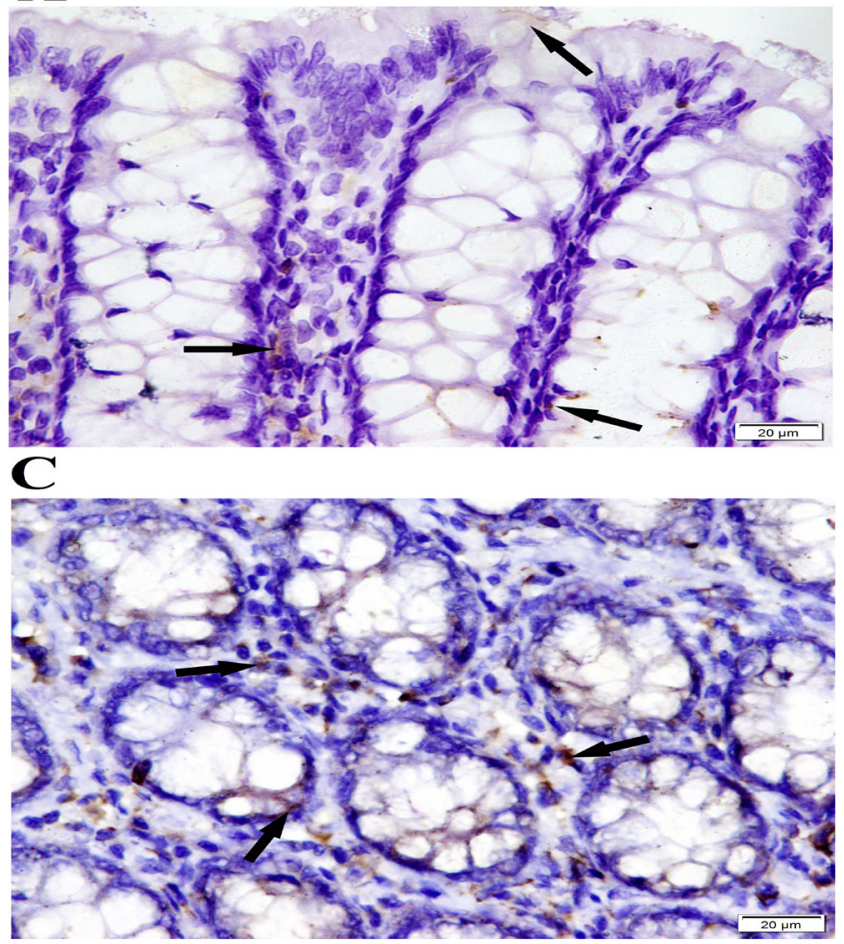

$\mathbf{B}$

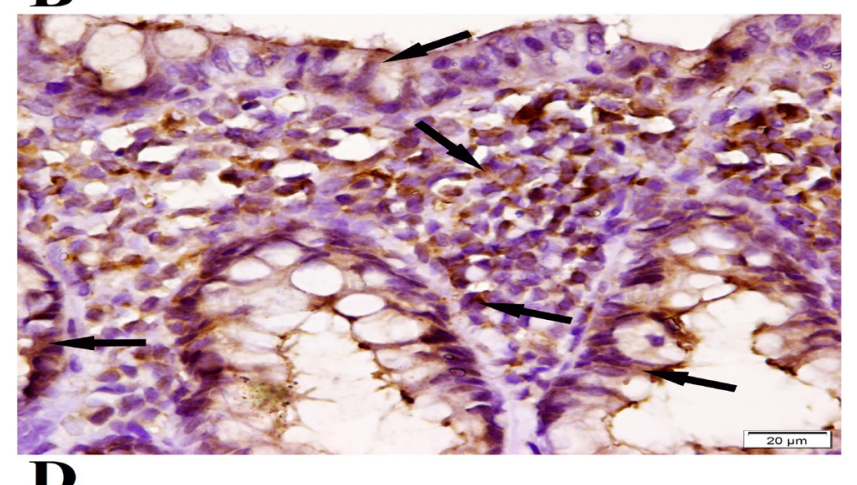

D

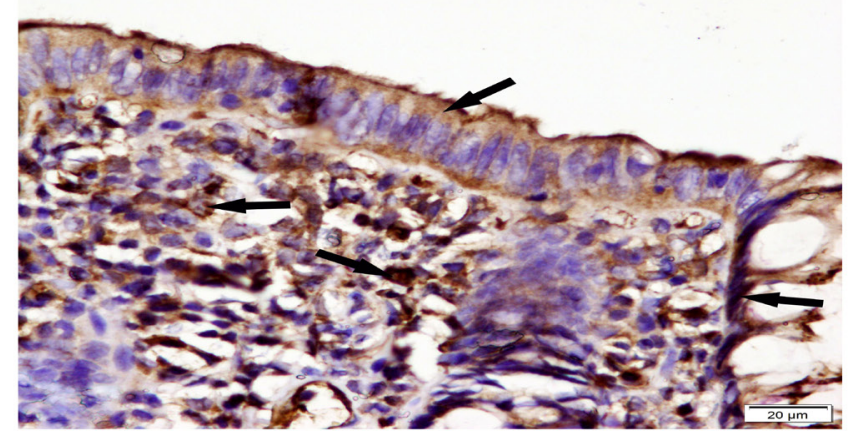

Fig. 7: Photomicrograph of a section in the colon of:

A: Control group illustrating very scanty brown cytoplasmic positive immunoreactivity in epithelial cells and few cells (arrows) in the connective tissue lamina propria of the mucosa. B: Colitis group demonstrating apparent marked increase in positive immunoreactivity in both epithelial and connective tissue lamina propria cells (arrows) of the mucosa. C: MVs treated group exhibiting apparent decrease in positive immunoreactivity in both epithelial and connective tissue lamina propria cells (arrows) of mucosa. D: RNase-MVs treated group demonstrating apparent marked increase in positive immunoreactivity in both epithelial and connective tissue lamina propria cells (arrows) of mucosa.

(iNOS: A,B,C \& D x400) 

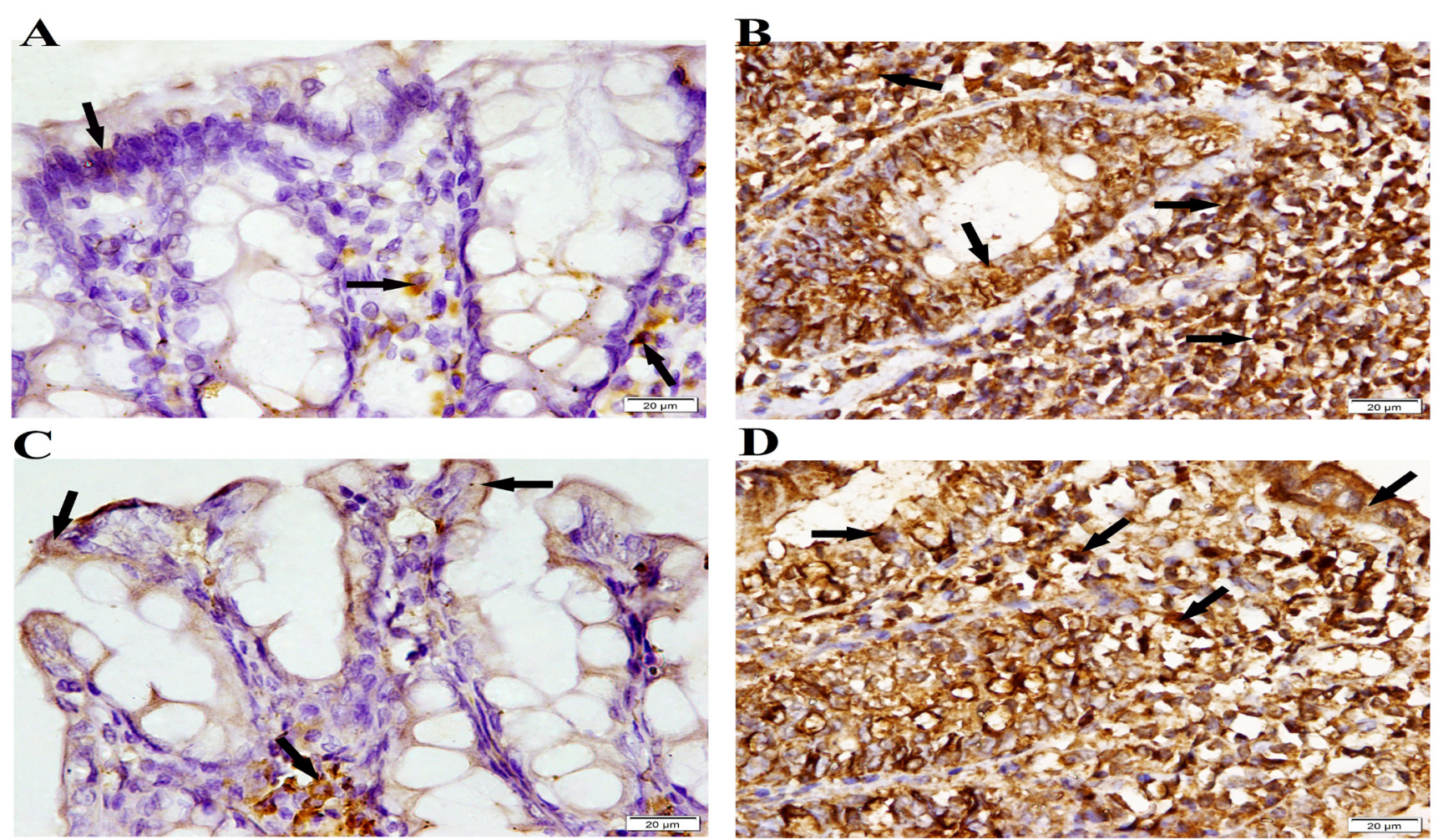

Fig. 8: Photomicrograph of a section in the colon of:

A: Control group revealing scarce positive immunoreaction in the surface epithelium and few connective tissue lamina propria cells (arrows) of the mucosa. B: Colitis group exhibiting markedly positive immunoreaction for COX-2 in both epithelial cells and connective tissue lamina propria cells (arrows) of the mucosa. C: MVs treated group demonstrating positive immunoreaction for COX-2 in some cells in lamina propria and epithelial cells (arrows). D: RNase-MVs treated group illustrating marked positive immunoreactivity for COX-2 in epithelial cells and lamina propria cells (arrows).

(COX-2: A,B,C and D x400)

Table 1: Myeloperoxidase enzyme levels mean values $( \pm \mathrm{SD})$ in the studied groups

\begin{tabular}{lc}
\hline Groups & Mean Values \pm SD of Myeloperoxidase levels \\
\hline Group I & $24.57 \pm 0.74$ \\
Group II & $68.08 \pm 1.15^{*}$ \\
Group III & $25.45 \pm 0.87 \#$ \\
Group IV & $67.73 \pm 0.88^{*}$ \\
\hline * A statistical significance versus to control at $P<0.05$.
\end{tabular}

\# A statistical significance versus to groups II and IV at $P<0.05$.

Table 2: Morphometric results mean values $( \pm \mathrm{SD})$ in the studied groups

\begin{tabular}{lcccc}
\hline & $\begin{array}{c}\text { Optical } \\
\% \pm \mathrm{SD} \text { of } \\
\text { Groups } \\
\text { Alcian blue } \\
+ \text { ve reaction }\end{array}$ & $\begin{array}{c}\text { Denisty } \\
\text { Alcian } \\
\text { blue }+ \text { ve } \\
\text { reaction }\end{array}$ & $\begin{array}{c}\text { Mean Area } \\
\% \pm \mathrm{SD} \\
\text { of iNOS } \\
\text { immunoreactivity }\end{array}$ & $\begin{array}{c}\text { Mean Area } \\
\% \pm \mathrm{SD} \text { of } \\
\mathrm{COX}-2 \\
\text { immunoreactivity }\end{array}$ \\
\hline Group I & $25.01 \pm 3.12$ & $0.75 \pm 0.05$ & $2.07 \pm 0.74$ & $6.70 \pm 1.71$ \\
Group II & $5.95 \pm 1.25 *$ & $0.25 \pm 0.03 *$ & $12.87 \pm 1.11 *$ & $20.09 \pm 2.23 *$ \\
Group III & $22.67 \pm 2.12 \#$ & $0.72 \pm 0.04 \#$ & $3.27 \pm 1.18 \#$ & $7.19 \pm 2.45 \#$ \\
Group IV & $6.55 \pm 1.69 *$ & $0.27 \pm 0.04 *$ & $12.99 \pm 1.13 *$ & $19.54 \pm 2.20^{*}$ \\
\hline * Statistically significant in comparison with control at $P<0.05$. \\
\# Statistically significant in comparison with groups II and IV at $P<0.05$.
\end{tabular}

\section{DISCUSSION}

Ulcerative colitis (UC) is considered an idiopathic inflammatory bowel disease (IBD) with recurrent massive inflammatory changes of the rectum and colon mucosa. Episodes of acute inflammation, ulceration and bleeding of colonic mucosa, are features of this disease. While numerous studies on UC pathogenesis have been conducted, therapies that are capable to cure it are not available. As a result the effective and full management of $\mathrm{UC}$ is still not achieved ${ }^{[31]}$.

Several induction models for UC in animals are present. Acetic acid (AA) induced colitis is a commonly used model which is easy to induce. Rectal administration of AA mimics the conditions that occurs in human UC and is useful for testing the effectiveness of remedies. It is characterized by its close similarity to UC in human beings as regards pathogenesis, histopathological features and inflammatory mediators ${ }^{[32}$ and 15$]$.

The MSCs release large amounts of EVs that are considered fundamental effectors of MSCs paracrine actions. Recent reports have elucidated that the main beneficial actions of stem cells are dedicated to their paracrine effects. They are not due to the ability of engraftment and differentiation at the injury site. Resembling their parent cells, MSC-EVs home to the inflammatory sites. Besides, they induce anti-inflammatory, immunoregulatory and regenerative effects. The exact mechanisms underlying these properties of MSC-EVs are still unexplained entirely ${ }^{[33,34,35}$ and 36].

Extracellular vesicles are membrane-bounded structures which are secreted via approximately all cell kinds toward 
the extracellular milieu. The most important types of EVs are microvesicles and exosomes. Microvesicles are bud offs of the plasmalemma and of 100-1000 nm diameter. Exosomes are late endosomal compartment derivatives and of 70-150 nm diameter. According to the type of the cell, the previously mentioned types of EVs are assembled along with specific protocols. Consequently, they contain particular mixtures of components such as RNA, lipids, cell adhesion molecules, cytokines and other proteins ${ }^{[37]}$.

These MSC-EVs are more handy and safe than MSCs. Also, on the contrary to cells, they do not have any probable tumorigenicity. Moreover, they can be safely stored without function loss ${ }^{[38}$ and 33].

Exosomes and microvesicles are discrete sorts of vesicles, however their diameter and morphology are not sufficient to discriminate between them. It is important to note that the size of MVs could overlap with the exosomes size range. Moreover, lack of specific markers make differentiation between different subtypes of vesicles very difficult. Thus, the Extracellular Vesicles International Society proposed that, it is preferred to utilize the expression EVs when describing preparations of vesicles from tissue cultures. Also, there are literatures which referred to exosomes and MVs more broadly as $\mathrm{EV}^{[39,40 \text { and }}$ 35].

In the present study, morphological alterations in colonic mucosa after induction of UC were in the form of destruction of crypts architecture, dilated irregular crypts, loss of surface epithelium and loss of goblet cells. Massive infiltration of the mucosa with inflammatory cells mainly lymphocytes was observed. In addition, eosinophils and neutrophils were detected. Also, accumulation of inflammatory cells inside crypts including neutrophils was seen. Besides, widening of the spaces between crypts denoting crypt loss was detected.

These findings were the same as those described by Sen et al. (2017) ${ }^{[41]}$, who stated that, massive damage of epithelial tissue and crypts, besides severe infiltration with inflammatory cells was observed in AA induced colitis group. Also, Niu et al. (2013) ${ }^{[42]}$ and de Santana Souza et al. (2017) ${ }^{[33]}$ reported the same findings in addition to depletion of goblet cells. Langner et al. (2014) ${ }^{[44]}$ demonstrated invasion of neutrophils, that reflect disease activity, within the lamina propria and/or crypt lumina (crypt abscess). Besides, dilated crypts was detected in UC. In addition, Geboes et al. (2014) ${ }^{[45]}$ reported that crypt loss was demonstrated by increased space in between crypts when compared to normal. Also, eosinophils infiltration in UC was reported by Zucker et al. (2015) ${ }^{[28]}$.

The loss of goblet cells was confirmed by morphometric measurements. Statistically significant reduction in the mean area percent and optical density of mucin secreting goblet cells in alcian blue stained sections was noted. This was consistent with findings of Rodriguez-Canales et al. (2016) ${ }^{[46]}$ and Zhang et al. (2017) ${ }^{[47]}$, who reported depletion of goblet cells in induced UC in alcian blue stained sections.
Depletion of goblet cells can be explained by being part of tissue destruction that occurs during the inflammatory process. Similarly, Kasinathan et al. (2018) ${ }^{[48]}$ stated that one of the key features of the acute inflammation during UC was the decreased number of mucus containing goblet cells. This inflammatory process also explains the findings detected in UC.

The etiology of UC is still not well known. One of the hallmarks of UC is inflammation. This uncontrolled inflammation is possibly the consequence of the interplay among many factors including; gene tendency, modifications and exaggerated response in the innate adaptive immunity. The intestinal damage induced by AA could explain the aforementioned findings. Colonic barrier damage followed by bacterial invasion most likely leads to inflammation. Inflammation leads to overproduction of inflammatory cytokines. Oxidative damage is also related to UC by the increase in reactive oxygen species (ROS) and nitric oxide synthase (NOS), with generation of free radicals. These factors lead to indiscriminate tissue damage and destruction of the colonic mucosa ${ }^{[49}$ and 50$]$.

In accordance with eosinophil biology, allergicmediated inflammation could be implicated in the pathogenesis of UC. Eosinophils are normally found in the mucosa of intestine. They have a key function in host defense. However, eosinophils increased numbers have been demonstrated in UC. Inflammation is promoted by eosinophils through secretion of granule's toxic proteins, free radicals and proinflammatory mediators ${ }^{[51-52]}$.

Polymorph nuclear leukocytes [PMNLs] have a major role in mucosal damage in UC as stated by Gupta et al. $(2015)^{[53]}$. Normally these cells are not found outside the lumen of capillaries in the lamina propria. Furthermore, more than three neutrophils outside capillaries would be considered abnormal. They are the first cells which migrate from capillaries to the damage site. Also, they are considered a distinctive feature of the inflammatory process ${ }^{[45]}$. In the present work, the presence of neutrophils in inflamed colonic tissues was observed in H\&E stained histological sections. Myeloperoxidase (MPO) is the predominant enzyme inside neutrophils' azurophilic granules. MPO levels in colon specimens are regarded as a quantitative and sensitive tool to detect acute inflammation in intestine. Consequently, it has been documented that increased MPO activity is considered an index of tissue infiltration with neutrophils and inflammatory reaction ${ }^{[54}$ and 48$]$.

Therefore, in this study, further confirmation of neutrophils accumulation was done by biochemical measurement of MPO amount in colon homogenates. A significant increase in colonic tissues MPO level was detected in rats of group II when compared to control. This was consistent with Dinc et al. (2015) ${ }^{[55]}$ results, who reported that the amount of MPO showed significant rise in AA induced colitis rats in relation to control.

In the current work, iNOS and COX-2 immunostaining were used to estimate the extent of inflammatory process 
in colitic rats. Morphometric measurements documented a statistically significant rise in the mean area\% of both iNOS and COX-2 immunostained sections of group II when compared to control. This was in accordance with Sakthivel and Guruvayoorappan, (2014) ${ }^{[56]}$ and Barbosa Bezerra et al. (2017) ${ }^{[18]}$. They reported that iNOS and COX-2 over expression was noted in AA induced colitis. Moreover, Pastrelo et al. (2017) ${ }^{[57]}$ stated that, inflammatory mediators such as iNOS and COX-2 upregulation in colon specimens during UC was associated with exacerbation, amplification and perpetuation of the inflammation.

Suluvoy et al. (2017) ${ }^{[58]}$ reported that enzymes like iNOS and COX-2 are the major enzymes upregulated or overexpressed during inflammation. They added that these inflammatory mediators reveal a defense mechanism against infection, damage and inflammatory process during pathologic state. The expression of iNOS in normal states could be detected in neutrophils, smooth muscle and sparse distribution within epithelial cells. The COX-2 expression in normal animals could be seen in the epithelium surface and lamina propria mononuclear cells.

iNOS is implicated in the pathogenesis of colitis. iNOS has the ability to synthesize large levels of NO that could interact with free radicals forming more toxic compounds. This induces detrimental modifications in the structure and function of DNA, proteins and lipids, triggering tissue damage ${ }^{[59,53 \text { and } 60]}$.

Cyclooxygenase (COX) enzyme catalyzes the formation of prostaglandins from arachidonic acid. COX-1 is responsible for the synthesis of prostaglandins, that have a role in physiological functions, such as maintaing the colon mucosa. On the other hand, COX-2 is involved in causing inflammation, apoptosis, cancer cell growth and angiogenesis ${ }^{[59}$ and 61$]$.

In the current work, homing of microvesicles to the inflamed colons was confirmed. Examination of unstained sections using fluorescent microscopy revealed PKH26 labeled microvesicles. They appeared like strong red fluorescent dots. This was in agreement with Wang et al. $(2018)^{[62]}$, who used fluorescent microscopy to trace the PKH26 labeled MSC-exosomes, that appeaed as red dots in the site of lesion.

In the present study, the rats which received MSCsMVs therapy after colitis induction demonstrated improvement in histological architecture of colon specimens. Morphometric analysis proved a statistically significant rise in the mean area percent as well as optical density of mucin in alcian blue stained sections. Similar findings were demonstrated by Yang et al. (2015) ${ }^{[23]}$ and Mao et al. (2017) ${ }^{[63]}$. They revealed that, attenuation of experimentally induced colitis was observed upon stem cells derived extracellular vesicles administration.

As mentioned previously, inflammation has a crucial role in UC pathogenesis. The present study assumed that the protecting effects of MSC-MVs could be owed to their anti-inflammatory, immunomodulatory and regenerative criteria exerted after homing to inflamed colons. Thus, down regulation of inflammatory mediators expression, in addition to reduction in inflammatory cells infiltration within colitic tissues could explain the marked attenuation in UC manifestations.

Going parallel with the aforementioned assumption, in the current work, biochemical assessment of MPO activity within colonic tissues exhibited marked decrease in this group in comparison with groups II and IV. This is in accordance with $\mathrm{Li}$ et al. (2016) ${ }^{[64]}$ who demonstrated that MSCs derived vesicles administration significantly reduced the number of MPO immunopositive neutrophils in relation to the skin burn induced inflammation group.

Moreover, our findings demonstrated significant decline in the mean area $\%$ of both iNOS and COX-2 immunostained sections of group III when compared to groups II and IV. This was consistent with Chen et al. (2016)[65] who reported that, ADMSC-derived exosome treatment significantly suppressed iNOS expression in a model of acute ischemic stroke. Also, Vonk et al. $(2018)^{[66]}$ reported that BM-MSC derived extracellular vesicles therapy significantly down regulated expression of $\mathrm{COX}-2$ in osteoarthritis cartilage inflammation.

In the current work, it was hypothesized that shuttling of various types of RNAs into target cells, triggers various genes expression encoding and controlling different pathways inside cells. This could explain the underlying mechanisms of such anti-inflammatory, immunomodulatory and reparative capabilities of MSCMVs. In order to elucidate the pivotal role of the RNAs content of MVs, the enclosed RNAs was depleted and the therapeutic potential of RNAs depleted MVs was tested in group IV.

This concept was consistent with Eirin et al. (2014) ${ }^{[67]}$, who concluded that specific combinations of mRNAs and microRNAs (miRNAs) are included inside MSC-EVs. These contents have the ability to regulate transcription of genetic information, thus controlling adipogenesis, angiogenesis and other pathways in target cells.

In addition, Chen et al. (2015) ${ }^{[68]}$ reported that, MVs serve as a means of transportation to transfer mRNA and miRNA into remote cells, thus modifying expression of the gene and participating in genetic material exchange between cells. Alteration of the expression of gene products in neighboring cells can be achieved by transferring miRNAs within MVs, as these miRNAs can naturally regulate translation of protein.

In the current study, homing of RNase treated MVs was confirmed by examination of unstained sections by fluorescent microscopy. PKH26 labeled vesicles demonstrated as strong red fluorescent dots within colon tissues. It is of note to postulate that, 
Gatti et al. (2011) ${ }^{[69]}$ reported no change in the expression of surface adhesion molecules of MVs that was treated with RNase. Furthermore, RNase treated MVs internalization into target cells was the same as untreated MVs.

In the present work, histological examination of colon sections of group IV revealed persistence of features of UC. Also, morphometric measurements of the mean area $\%$ and optical density of alcian blue stained sections showed statistically significant decrease in relation to control. Furthurmore, MPO activity was markedly elevated in colonic tissues of rats in group IV when compared to control.

This was in accordance with Ranghino et al. (2017)[70] who reported that, ribonuclease (RNase) treatment of EV degraded vesicle-associated RNA. Besides, RNase-treated EVs were useless in amelioration of histological recovery of the kidney after ischemia-reperfusion injury (IRI). Similarly, Cheng et al. (2017) ${ }^{[71]}$ stated that, down regulation of exosomal RNA levels strikingly concealed their positive effects on reducing apoptosis of the cells of nucleus pulposus and degeneration of intervertebral disc.

Also, morphometric analysis of the mean area $\%$ of iNOS and COX-2 stained sections of this group, demonstrated a statistically significant elevation versus control. This was consistent with Collino et al. (2015) ${ }^{[72]}$. They declared that, EVs therapy restored the upregulation of inflammatory genes to normal. Downregulation of RNAs in EVs abolished this effect.

Likewize, de Almeida et al. (2017) ${ }^{[73]}$ reported that, administration of MVs pretreated with RNases eliminated the reduction in the amount of serum inflammatory cytokines. Moreover, pretreatments of MVs with DNases and proteases did not affect the therapeutic capability of MVs.

Altogether, the aforementioned data suggest that depletion of vesicles RNA content inhibited their beneficial effects. Owing to this, the mechanism of action of MVs depends mainly on the different types of RNA present inside these vesicles.

In conclusion, MSC-MVs were capable of repairing the histological architecture of colitic mucosa. Inflammatory mediators expression and inflammatory cells infiltration was suppressed after application of MVs. Being feasible and safe, MVs have been proposed as an alternative curative tool for MSCs. Eventually, MSC-MVs could be considered a promising therapeutic agent in UC management. Moreover, elimination of vesicular RNA content significantly deteriorated the beneficial effects of MVs. Further investigations are recommended to determine the role of other substances enclosed within the vesicles. Also, future studies should be done to detect the specific types of vesicular RNA implicated in such reparative effects in $\mathrm{UC}$.

\section{CONFLICTS OF INTEREST}

The authors have no conflicts of interest to declare.

\section{REFERENCES}

1. Gonczi L, Kurti Z, Golovics PA, Lovasz BD, Menyhart O, Seres A, Sumegi LD, Gal A, Ilias A, Janos P, Gecse KB, Bessisow T, Afif W, Bitton A, Vegh Z and Lakatos PL: Quality of care indicators in inflammatory bowel disease in a tertiary referral center with open access and objective assessment policies in Dig Liver Dis. (2018) 50(1): 37-41.

2. Meijer B, van Everdingen CK, Ramsoekh D, Stedman C, Frampton CMA, Mulder CJJ, Bouma G, de Boer NKH and Gearry RB: Transient elastography to assess liver stiffness in patients with inflammatory bowel disease in Dig Liver Dis. (2018) 50(1): 48-53.

3. Bao X, Feng Z, Yao J, Li T and Yin Y: Roles of Dietary Amino Acids and Their Metabolites in Pathogenesis of Inflammatory Bowel Disease in Mediators Inflamm.. (2017) 2017: 1-9.

4. Block M, Mölne J, Leffler H, Börjesson L and Breimer ME: Immunohistochemical Studies on Galectin Expression in Colectomised Patients with Ulcerative Colitis in Biomed Res Int. (2016) 2016: 1-10.

5. Lin S, Wang J, Wang L, Wen J, Guo Y, Qiao W, Zhou J, Xu G and Zhi F: Phosphodiesterase-5 inhibition suppresses colonic inflammationinduced tumorigenesis via blocking the recruitment of MDSC in Am J Cancer Res. (2017) 7(1): 41-52.

6. Shi X, Yan Y, Wang P, Sun Y, Zhang D, Zou Y, $\mathrm{Hu}$ S, Zhang L, Xing J and Dong Y: In vitro and in vivo study of $\mathrm{pH}$-sensitive and colon-targeting P(LE-IA-MEG) hydrogel microspheres used for ulcerative colitis therapy in Eur J Pharm Biopharm. (2018) 122: 70-77.

7. Chen Q, Duan X, Fan H, Xu M, Tang Q, Zhang L, Shou Z, Liu X, Zuo D, Yang J, Deng S, Dong Y, Wu H, Liu Y and Nan Z: Oxymatrine protects against DSS-induced colitis via inhibiting the PI3K/AKT signaling pathway in Int Immunopharmacol. (2017) 53: 149-157.

8. Liang J, Chen S, Chen J, Lin J, Xiong Q, Yang Y, Yuan J, Zhou L, He L, Hou S, Li S, Huang S and Lai X: Therapeutic roles of polysaccharides from Dendrobium Officinaleon colitis and its underlying mechanisms in Carbohydr Polym. (2018) 185: 159-168. 
9. Klinker MW and Wei $\mathrm{CH}$ : Mesenchymal stem cells in the treatment of inflammatory and autoimmune diseases in experimental animal models in World $\mathrm{J}$ Stem Cells. (2015) 7(3): 556-567.

10. Sun T, Gao GZ, Li RF, Li X, Li DW, Wu SS, Yeo AET and Jin B: Bone marrow-derived mesenchymal stem cell transplantation ameliorates oxidative stress and restores intestinal mucosal permeability in chemically induced colitis in mice in Am J Transl Res. (2015) 7(5): 891-901.

11. Gregoire C, Lechanteur C, Briquet A, Baudoux E, Baron F, Louis E and Beguin Y: Review article: mesenchymal stromal cell therapy for inflammatory bowel diseases in Aliment Pharmacol Ther. (2017) 45(2): 205-221.

12. Aghajani Nargesi A, Lerman LO and Eirin A: Mesenchymal stem cell-derived extracellular vesicles for kidney repair: current status and looming challenges in Stem Cell Res Ther. (2017) 8(1): 273-284.

13. Haga H, Yan IK, Takahashi K, Matsuda A, Patel T: Extracellular Vesicles from Bone Marrow-Derived Mesenchymal Stem Cells Improve Survival from Lethal Hepatic Failure in Mice in Stem Cells Transl Med. (2017) 6(4): 1262-1272.

14. Wang N, Chen C, Yang D, Liao Q, Luo H, Wang $X$, Zhou $F$, Yang $X$, Yang J, Zeng $C$ and Wang WE: Mesenchymal stem cells-derived extracellular vesicles, via miR-210, improve infarcted cardiac function by promotion of angiogenesis in Biochim Biophys Acta Mol Basis Dis. (2017)1863(8): 2085-2092.

15. Tanideha N, Jamshidzadeh A, Saghesloo AG, Rahmanifar F, Mokhtari M, Koohi-Hosseinabadi O, Omidi M, Najibi A: Effects of hydroalcoholic extract of Ziziphus jujube on acetic acid induced ulcerative colitis in male rat (Rattus norvegicus) in J Coloproctol (RIO J). (2016) 36(4): 189-195.

16. Senol A, Isler M, Sutcu R, Akin M, Cakir E, Ceyhan BM and Kockar MC: Kefir treatment ameliorates dextran sulfate sodium-induced colitis in rats in World J Gastroenterol. (2015) 21(46): 13020-13029.

17. Cagin YF, Parlakpinar H, Vardi N, Polat A, Atayan Y, Erdogan MA and Tanbek K: Effects of dexpanthenol on acetic acid-induced colitis in rats in Exp Ther Med. (2016) 12(5): 2958-2964.

18. Barbosa Bezerra G, de Menezes de Souza L, Dos Santos AS, de Almeida GK, Souza MT, Santos SL, Aparecido Camargo E, Dos Santos Lima B, de Souza Araújo AA, Cardoso JC, Gomes SV, Gomes MZ and de Albuquerque RL Júnior: Hydroalcoholic extract of Brazilian red propolis exerts protective effects on acetic acid-induced ulcerative colitis in a rodent model in Biomed Pharmacother. (2017) 85: 687-696.

19. Ozsoy Z, Ozsoy S, Gevrek F, Demir E, Benli I, Daldal E and Yenidogan E: Effect of bevacizumab on acetic acid-induced ulcerative colitis in rats in $\mathrm{J}$ Surg Res. (2017) 216: 191-200.

20. Zou X, Zhang G, Cheng Z, Yin D, Du T, Ju G, Miao S, Liu G, Lu M and Zhu Y: Microvesicles derived from human Wharton's Jelly mesenchymal stromal cells ameliorate renal ischemia-reperfusion injury in rats by suppressing CX3CL1 in Stem Cell Res Ther. (2014) 5(2): 40-53.

21. Mumaw JL, Schmiedt CW, Breidling S, Sigmund A, Norton NA, Thoreson M, Peroni JF and Hurley DJ: Feline mesenchymal stem cells and supernatant inhibit reactive oxygen species production in cultured feline neutrophils in Res Vet Sci. (2015)103: 60-69.

22. Bruno S, Grange C, Collino F, Deregibus MC, Cantaluppi V, Biancone L, Tetta C and Camussi G: Microvesicles Derived from Mesenchymal Stem Cells Enhance Survival in a Lethal Model of Acute Kidney Injury in PLoS ONE. (2012) 7(3): 1-11.

23. Yang J, Liu XX, Fan H, Tang Q, Shou ZX, Zuo DM, Zou Z, Xu M, Chen QY, Peng Y, Deng SJ and Liu YJ: Extracellular Vesicles Derived from Bone Marrow Mesenchymal Stem Cells Protect against Experimental Colitis via Attenuating Colon Inflammation, Oxidative Stress and Apoptosis in PLoS ONE (2015) 10(10): 1-19.

24. Matuszyk A, Ceranowicz P, Warzecha Z, Cieszkowski J, Gałązka K, Bonior J, Jaworek J, Konturek PC, Gil K and Dembiński A: Pretreatment with obestatin inhibits the development of acetic acid-induced colitis in rats in Arch Med Sci. (2018) 14(4):920-929.

25. Kiernan J: Histological and Histochemical Methods: Theory and Practice.5th ed., Scoin publisher, United Kingdom. (2015) pp: 111-162.

26. Suvarna K, Layton Ch and Bancroft J: Bancroft's theory and practice of histological techniques. 8th ed., Churchill Livingstone, Philadelphia. (2013) pp: 373-391.

27. Bancroft JD and Gamble M: Theory and practice of histological techniques. 6th ed., Churchill Livingstone Elsevier, China. (2008) pp: 433-472.

28. Zucker SD, Vogel ME, Kindel TL, Smith DL, Idelman G, Avissar U, Kakarlapudi G and Masnovi ME: Bilirubin prevents acute DSS-induced colitis by inhibiting leukocyte infiltration and suppressing upregulation of inducible nitric oxide synthase in Am J Physiol Gastrointest Liver Physiol. (2015) 309(10):G841-854. 
29. Zhang W, Pan Y, Qu S, Wang D, Cheng S and Liu X: Anti-Inflammatory Effects of an Extract of Polygonum hydropiper Stalks on 2,4,6-Trinitrobenzenesulphonic Acid-Induced Intestinal Inflammation in Rats by Inhibiting the NF- $\kappa B$ Pathway in Mediators Inflamm. (2018) 2018(1):1-10.

30. Emsley R, Dunn G and White IR: Mediation and moderation of treatment effects in randomized controlled trials of complex interventions in Stat Methods Med Res. (2010) 19(3): 237-270.

31. Karakoyun B, Ertaş B, Yüksel M, Akakın D, Çevik Ö and Şener G: Ameliorative effects of riboflavin on acetic acid-induced colonic injury in rats in Clin Exp Pharmacol Physiol. (2018) 45(6):563-572.

32. Randhawa PK, Singh K, Singh N and Jaggi AS: A Review on Chemical-Induced Inflammatory Bowel Disease Models in Rodents in Korean J Physiol Pharmacol. (2014) 18(4): 279-288.

33. Rani S, Ryan AE, Griffin MD and Ritter T: Mesenchymal Stem Cell-derived Extracellular Vesicles: Toward Cell-free Therapeutic Applications in Mol Ther. (2015) 23(5): 812-823.

34. Eirin A, Zhu XY, Puranik AS, Woollard JR, Tang H, Dasari S, Lerman A, van Wijnen AJ and Lerman LO: Comparative proteomic analysis of extracellular vesicles isolated from porcine adipose tissue-derived mesenchymal stem/stromal cells in Sci Rep. (2016) 6: 1-12.

35. Chen B, Li Q, Zhao B and Wang Y: Stem CellDerived Extracellular Vesicles as a Novel Potential Therapeutic Tool for Tissue Repair in Stem Cells Transl Med. (2017) 6(9): 1753-1758.

36. Xiang C, Yang K, Liang Z, Wan Y, Cheng Y, Ma D, Zhang H, Hou W and Fu P: Sphingosine1-phosphate mediates the therapeutic effects of bone marrow mesenchymal stem cell-derived microvesicles on articular cartilage defect in Transl Res. (2018) 193: 42-53.

37. Drommelschmidt K, Serdar M, Bendix I, Herz J, Bertling F, Prager S, Keller M, Ludwig AK, Duhan V, Radtke S, de Miroschedji K, Horn PA, van de Looij Y, Giebel B, Felderhoff-Müser U: Mesenchymal stem cell-derived extracellular vesicles ameliorate inflammation-induced preterm brain injury in Brain Behav Immun. (2017) 60: 220-232.

38. Lener T, Gimona M, Aigner L, Börger V, Buzas E, Camussi G, Chaput N, Chatterjee D, Court FA, Del Portillo HA et al.: Applying extracellular vesicles based therapeutics in clinical trials - an ISEV position paper in J Extracell Vesicles. (2015) 4(1):30087-30117.
39. Gould SJ and Raposo G: As we wait: coping with an imperfect nomenclature for extracellular vesicles in J Extracell Vesicles. (2013) 2(1): 20389-20391.

40. Lawson C, Vicencio JM, Yellon DM and Davidson SM: Microvesicles and exosomes: new players in metabolic and cardiovascular disease in $\mathrm{J}$ Endocrinol. (2016) 228(2): R57-71.

41. Sen A, Yuksel M, Bulut G, Bitis L, Ercan F, Ozyilmaz-Yay N, Akbulut O, Cobanoglu H, Ozkan S and Sener G: Therapeutic Potential Of Myrtus Communis Subsp.Communis Extract Against Acetic Acid-Induced Colonic Inflammation In Rats in Journal of Food Biochemistry. (2017) 41: $1-10$.

42. Niu X, Fan T, Li W, Huang H, Zhang Y and Xing $\mathrm{W}$ : Protective effect of sanguinarine against acetic acid-induced ulcerative colitis in mice in Toxicol Appl Pharmacol. (2013) 267(3): 256-265.

43. de Santana Souza MT, Teixeira DF, de Oliveira JP, Oliveira AS, Quintans-Júnior LJ, Correa CB and Camargo EA: Protective effect of carvacrol on acetic acid-induced colitis in Biomed Pharmacother. (2017) 96: 313-319.

44. Langner C, Magro F, Driessen A, Ensari A, Mantzaris GJ, Villanacci V, Becheanu G, Borralho Nunes P, Cathomas G, Fries W, Jouret-Mourin A, Mescoli C, de Petris G, Rubio CA, Shepherd NA, Vieth M, Eliakim R, Geboes K; European Society of Pathology; European Crohn's and Colitis Foundation: The histopathological approach to inflammatory bowel disease: a practice guide in Virchows Arch. (2014) 464(5): 511-527.

45. Geboes K, Nemolato S, Leo M and Faa G: Colitis: A Practical Approach to Colon Biopsy Interpretation. Springer International Publishing, Switzerland. (2014) pp: 12-36.

46. Rodriguez-Canales M, Jimenez-Rivas R, CanalesMartinez MM, Garcia-Lopez AJ, Rivera-Yañez N, Nieto-Yañez O, Ledesma-Soto Y, SanchezTorres LE, Rodriguez-Sosa M, Terrazas LI and Rodriguez-Monroy MA: Protective Effect of Amphipterygium adstringens Extract on Dextran Sulphate Sodium-Induced Ulcerative Colitis in Mice in Mediators Inflamm. (2016) 2016: 1-12.

47. Zhang Z, Wu X, Cao S, Cromie M, Shen Y, Feng Y, Yang $\mathrm{H}$ and Li L: Chlorogenic Acid Ameliorates Experimental Colitis by Promoting Growth of Akkermansia in Mice in Nutrients. (2017) 9(7): 1-13.

48. Kasinathan NK, Subramaniya B and Sivasithamparam ND: NF- $\mathrm{B} /$ twist mediated regulation of colonic inflammation by lupeol in abating dextran sodium sulfate induced colitis in mice in Journal of Functional Foods. (2018) 41: 
240-249.

49. Colares JR, Schemitt EG, Hartmann RM, Moura RM, Morgan-Martins MI, Fillmann HS, Fillmann L and Marroni NP: Effect of lecithin on oxidative stress in an experimental model of rats colitis induced by acetic acid in J Coloproctol (RIO J). (2016) 36(2): 97-103.

50. Moura RM, Hartmann RM, Licks F, Schemitt EG, Colares JR, Soares MDC, Fillmann LS, Fillmann HS and Marroni NP: Antioxidant effect of mesalazine in the experimental colitis model induced by acetic acid in J Coloproctol (RIO J). (2016) 36(3): 139-148.

51. Lampinen M, Rönnblom A, Amin K, Kristjansson G, Rorsman F, Sangfelt P, Säfsten B, Wagner $\mathrm{M}$, Wanders A, Winqvist $\mathrm{O}$ and Carlson $\mathrm{M}$ : Eosinophil granulocytes are activated during the remission phase of ulcerative colitis in Gut. (2005) 54(12):1714-1720.

52. Barrie A, Mourabet ME, Weyant K, Clarke K, Gajendran M, Rivers C, Park SY, Hartman D, Saul M, Regueiro M, Yadav D and Binion DG: Recurrent blood eosinophilia in ulcerative colitis is associated with severe disease and primary sclerosing cholangitis in Dig Dis Sci. (2013) 58(1): 222-228.

53. Gupta RA, Motiwala MN, Dumore NG, Danao KR and Ganjare $\mathrm{AB}$ : Effect of piperine on inhibition of FFA induced TLR4 mediated inflammation and amelioration of acetic acid induced ulcerative colitis in mice in Journal of Ethnopharmacol. (2015) 164: 239-246.

54. Pamukcu O, Kumral ZNO, Ercan F, Yegen BC and Ertem D: Anti-inflammatory effect of obestatin and ghrelin in dextran sulfate sodium-induced colitis in rats in J Pediatr Gastroenterol Nutr. (2013) 57(2): 211-218.

55. Dinc S, Caydere M, Akgul G, Yenidogan E, Hücümenoglu S and Rajesh M: Methylene Blue inhibits the inflammatory process of the acetic acid-induced colitis in the rat colonic mucosa in Int Surg. (2015) 100(11): 1364-1374.

56. Sakthivel KM and Guruvayoorappan C: Modulating effect of Biophytum sensitivum extract on rats with acetic acid-induced ulcerative colitis in Pharm Biol. (2014) 52 (12): 1570-1580.

57. Pastrelo MM, Ribeiro CCD, Duarte JW, Gollücke APB, Artigiani-Neto R, Ribeiro DA, Miszputen SJ, Fujiyama Oshima CT and Paiotti APR: Effect of Concentrated Apple Extract on Experimental Colitis Induced by Acetic Acid in Int J Mol Cell Med. (2017) 6(1): 38-49.

58. Suluvoy JK, Sakthivel KM, Guruvayoorappan C and Grace VMB: Protective effect of Averrhoa bilimbi L. fruit extract on ulcerative colitis in wistar rats via regulation of inflammatory mediators and cytokines in Biomed Pharmacother. (2017) 91: 1113-1121.

59. Fang J, Seki T, Tsukamoto T, Qin H, Yin H, Liao L, Nakamura $\mathrm{H}$ and Maeda $\mathrm{H}$ : Protection from inflammatory bowel disease and colitis-associated carcinogenesis with 4-vinyl-2,6-dimethoxyphenol (canolol) involves suppression of oxidative stress and inflammatory cytokines in Carcinogenesis. (2013) 34(12): 2833-2841.

60. Araújo DFS, Guerra GCB, Pintado MME, Sousa YRF, Algieri F, Rodriguez-Nogales A, Araújo RF Jr, Gálvez J, Queiroga RCRE, Rodriguez-Cabezas ME: Intestinal anti-inflammatory effects of goat whey on DNBS-induced colitis in mice in PLoS One. (2017) 12(9):1-19.

61. Jalalabadi Y, Shirazi A, Ghavam-Nasiri MR, Aledavood SA, Sardari D, Memar B, Shahidsales $\mathrm{S}$, Tabrizi FV, Dehghan $\mathrm{P}$ and Vosughiniya $\mathrm{H}$ : Evaluating the expression of cyclooxygenase-2 enzyme by immunohistochemistry in normal and tumoral tissue before and after neoadjuvant chemoradiotherapy in patients with esophageal cancer in Khorasan Province in J Cancer Res Ther. (2018) 14(3): 509-515.

62. Wang L, Pei S, Han L, Guo B, Li Y, Duan R, Yao Y, Xue B, Chen X and Jia Y: Mesenchymal Stem Cell-Derived Exosomes Reduce A1 Astrocytes via Downregulation of Phosphorylated NFкB P65 Subunit in Spinal Cord Injury in Cell Physiol Biochem. (2018) 50(4): 1535-1559.

63. Mao F, Wu Y, Tang X, Kang J, Zhang B, Yan Y, Qian $\mathrm{H}$, Zhang $\mathrm{X}$ and $\mathrm{Xu} \mathrm{W}$ : Exosomes Derived from Human Umbilical Cord Mesenchymal Stem Cells Relieve Inflammatory Bowel Disease in Mice in Biomed Res Int. (2017) 2017: 1-12.

64. Li X, Liu L, Yang J, Yu Y, Chai J, Wang L, Ma $\mathrm{L}$ and Yin H: Exosome Derived From Human Umbilical Cord Mesenchymal Stem Cell Mediates MiR-181c Attenuating Burn-induced Excessive Inflammation in EBioMedicine. (2016) 8: 72-82.

65. Chen $\mathrm{KH}$, Chen $\mathrm{CH}$, Wallace CG, Yuen CM, Kao GS, Chen YL, Shao PL, Chen YL, Chai HT, Lin KC, Liu CF, Chang HW, Lee MS and Yip HK: Intravenous administration of xenogenic adiposederived mesenchymal stem cells (ADMSC) and ADMSC-derived exosomes markedly reduced brain infarct volume and preserved neurological function in rat after acute ischemic stroke in Oncotarget. (2016) 7(46): 74537-74556.

66. Vonk LA, van Dooremalen SFJ, Liv N, Klumperman J, Coffer PJ, Saris DBF and 
Lorenowicz MJ: Mesenchymal Stromal/stem Cellderived Extracellular Vesicles Promote Human Cartilage Regeneration In Vitro in Theranostics. (2018) 8(4): 906-920.

67. Eirin A, Riester SM, Zhu XY, Tang H, Evans JM, O'Brien D, van Wijnen AJ and Lerman LO: MicroRNA and mRNA cargo of extracellular vesicles from porcine adipose tissue-derived mesenchymal stem cells in Gene. (2014) 551(1): 55-64.

68. Chen J, Li C and Chen L: The Role of Microvesicles Derived from Mesenchymal Stem Cells in Lung Diseases in Biomed Res Int. (2015) 2015:1-6.

69. Gatti S, Bruno S, Deregibus MC, Sordi A, Cantaluppi V, Tetta C and Camussi G: Microvesicles derived from human adult mesenchymal stem cells protect against ischaemia-reperfusion-induced acute and chronic kidney injury in Nephrol Dial Transplant. (2011) 26(5):1474-1483.

70. Ranghino A, Bruno S, Bussolati B, Moggio A, Dimuccio V, Tapparo M, Biancone L, Gontero P, Frea B, Camussi G: The effects of glomerular and tubular renal progenitors and derived extracellular vesicles on recovery from acute kidney injury in Stem Cell Res Ther. (2017) 8(1): 1-15.

71. Cheng X, Zhang G, Zhang L, Hu Y, Zhang K, Sun X, Zhao C, Li H, Li YM and Zhao J: Mesenchymal stem cells deliver exogenous miR-21 via exosomes to inhibit nucleus pulposus cell apoptosis and reduce intervertebral disc degeneration in $\mathrm{J}$ Cell Mol Med. (2018) 22(1): 261-276.

72. Collino F, Bruno S, Incarnato D, Dettori D, Neri F, Provero P, Pomatto M, Oliviero S, Tetta C, Quesenberry PJ, Camussi G: AKI Recovery Induced by Mesenchymal Stromal Cell-Derived Extracellular Vesicles Carrying MicroRNAs in J Am Soc Nephrol. (2015) 26(10): 2349-2360.

73. de Almeida DC, Bassi EJ, Azevedo H, Anderson L, Origassa CST, Cenedeze MA, de AndradeOliveira V, Felizardo RJF, da Silva RC, Hiyane MI, Semedo P, dos Reis MA, Moreira-Filho CA, Verjovski-Almeida S, Pacheco-Silva A and Camara NOS: A Regulatory miRNA-mRNA Network Is Associated with Tissue Repair Induced by Mesenchymal Stromal Cells in Acute Kidney Injury in Front Immunol. (2017) 7: 1-18. 


\section{الملخص العربى}

\section{دراسه هستولوجيه عن تأثثير الحويصلات الاقيقه المشتقه من الخلايا

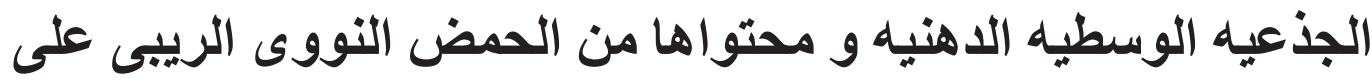 إلتهاب القولون التقرحى المحدث تجريبيا فى الجرذان البيضاء}

\section{منال على عبدالمحسن، مروه محمد صبرى}

قسم علم الأنسجه ـ كلية الطب - جامعة القاهره

الخلقية: التهاب القولون التقرحي هو التهاب يصيب الأمعاء، والذي يتميزبنوبات من آلام في البطن والإسهال الدموي. حتي الان، خيار ات العلاج ليست مرضية بالاضافه الي مضاعفاتها المختلفة. لذلك تعثبر الحويصلات الدقيقه المشتقه من الخليه الجذعيه الوسطيه المشتقه من النسيج الدهنى من العو امل العلاجية البديلة الواعدة الناشئة. الهـف من العمل: تقييم الإمكانات العلاجية للحويصلات الدقيقه المشتقه من الخليه الجذعيه الوسطيه على التهاب القولون التقرحي المحدث بحامض الخليك، بالإضافة إلى الدور المحتمل لمحتوى الحمض النووى الريبى الخاص به. مواد وطرق البحث: تم تقسيم أربعين من ذكور الجرذان البيضاء إلى أربع مجموعات: المجموعة الأولى (المجموعة الضابطة)، المجموعة الثانية (التهاب القولون)، المجموعة الثالثة (التهاب القولون المعالجة بالحويصلات الدقيقة) و المجموعة الر ابعة (التهاب القولون المعالجة بالحويصلات الدقيقة الخاليه من الحمض النووى الريبى). تم احداث التهاب القولون عن طريق حقن الجرذان البيضاء بحامض الخليك من خلال حقنه شرجية في المجمو عات الثانية و الثالثة و الر ابعة. و في اليوم الثالث بعد الحقنة الثرجية تم حقن المجموعه الثانيه وريديا بمحلول ملحي معالج بالفوسفات و تم حقن المجموعه الثالثه وريديا بالحويصلات الدقيقة المستمدة من الخلايا الجذعية الوسطيه و تم حقن المجموعه الر ابعة وريديا بالحويصلات الدقيقة المستمدة من الخلايا الجذعية الوسطيه و الخاليه من الحمض النووى الريبى. وبعد

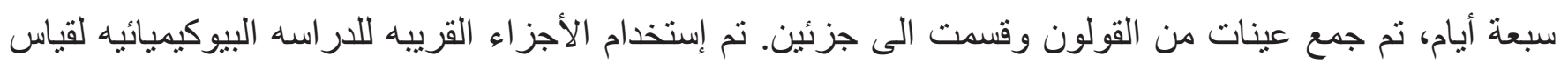
مستويات إنزيم الميلوبيروكسيديز. تم تجهيز الأجزاء البعيده للهيماتوكسيلين والإيوسين, الالثيان الأزرق و الصبغة الهيتوكيمبائية المناعية ضد مصنع اكسيد النيتر ات المستحث و انزيم الأكسده الحلقيه2. تم إجر اء تحليل مورفومترى و إحصائي. النتائج: أظهرت المجموعة الثالثة تحسن في الخصائص النسيجية لالتهاب القولون التقرحي و زيادة ملحوظة في متوسط نسبة المساحة والكثافة البصرية للميوسين. كما أظهرت انخفاضًا ملحوظا في التفاعل المناعى لمصنع اكسيد النيتر ات المستحث و انزيم الأكسده الحلقبه2 و مستويات انزيم الميلوبيروكسيديز. الاستتتاج: استخدام الحويصلات الدقيقة المشتقه من الخلايا الجذعية الوسطيه يؤدى الى تحسين التهاب القولون التقرحي. وقد تم اثبات ان محتوى هذه الحويصلات من الحمض النووي الريبي له دور حاسم في مثل هذه الآثار الوقائية. وبالتالي، يمكن أن تكون الحويصلات الدقيقة المشتقه من الخلايا الجذعية الوسطيه أداة واعدة في علاج التهاب القولون التقرحي. 


\section{Authors Query Forms}

Journal Name : EJH

Article No:

Queries and Remarks

\begin{tabular}{|c|c|c|}
\hline Query No & Details Required & Author Resporns \\
\hline Q1 & Please provide the running tittle in page 394 & \\
\hline
\end{tabular}

